\title{
Health care for LGBTI+ elders living in Nursing Homes
}

\author{
Assistência à saúde de residentes LGBTI+ em Instituições de Longa Permanência para Idosos \\ Atención de salud para residents LGBTI+ en Hogares para Ancianos
}

\section{Jumar Reis da Silva Junior' \\ ORCID: 0000-0002-7431-3419 \\ Letícia Diniz França' \\ ORCID: 0000-0002-0889-6636 \\ Anderson Rosa' \\ ORCID: 0000-0003-4683-3107 \\ Vanessa Ribeiro Neves' \\ ORCID: 0000-0002-2226-4723 \\ Lucíola D'Emery Siqueira' ORCID: 0000-0001-5087-9824}

'Universidade Federal de São Paulo. São Paulo, São Paulo, Brazil.

How to cite this article:

Silva Jr JR, França LD, Rosa A, Neves VR, Siqueira LD. Health care for LGBTI+ elders living in Nursing Homes. Rev Bras Enferm. 2021;74(Suppl 2):e20200403. doi: http://dx.doi.org/10.1590/0034-7167-2020-0403

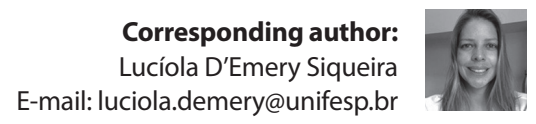

EDITOR IN CHIEF: Dulce Barbosa ASSOCIATE EDITOR: Hugo Fernandes

Submission: $07-10-2020$

Approval: 11-01-2020

\section{ABSTRACT}

Objective: to describe and analyze the scientific production on health care for Lesbians, Gays, Bisexuals, Transvestites, Transsexuals, Transgenders, Intersex (LGBTI+) and other variations of gender or sexual orientation living in Nursing Homes (NHs). Methods: a scoping review, in which PubMed, Web of Science, Scopus and Virtual Health Library databases were analyzed and studies from other sources were added. After assessment by two independent reviewers, 19 publications were selected to compose the sample. Results: the studies were grouped into two categories. Final considerations: $\mathrm{NHs}$ are configured as spaces that are not very inclusive, where LGBTI+ elders' demands are not considered due to the cis-heteronormativity in force in these places. Training and awareness of health professionals on the LGBTI+ theme is a tool that can make such spaces more inclusive for this population.

Descriptors: Sexual and Gender Minorities; Homes for the Aged; Delivery of Health Care; Nursing; Health Personnel.

\section{RESUMO}

Objetivo: descrever e analisar a produção científica sobre a assistência à saúde da população de Lésbicas, Gays, Bissexuais, Travestis, Transexuais, Transgêneros, Intersexuais (LGBTI+) e outras variações de gênero ou orientação sexual residentes em Instituições de Longa Permanência para Idosos (ILPI). Métodos: revisão de escopo, em que foram analisadas as bases de dados PubMed, Web of Science, Scopus e Biblioteca Virtual da Saúde e acrescentados estudos de outras fontes. Após avaliação de dois revisores independentes, foram selecionadas 19 publicações para compor a amostra. Resultados: os estudos foram agrupados em duas categorias. Considerações finais: as ILPI configuram-se como espaços pouco inclusivos, onde as demandas da população idosa LGBTI+ não são consideradas devido à cis-heteronormatividade vigentes nesses locais. $O$ treinamento e a sensibilização dos profissionais de saúde quanto à temática LGBTI+é uma ferramenta que pode tornar tais espaços mais inclusivos para essa população. Descritores: Minorias Sexuais e de Gênero; Instituição de Longa Permanência para Idosos; Assistência à Saúde; Enfermagem; Pessoal de Saúde.

\section{RESUMEN}

Objetivo: describir y analizar la producción científica sobre el cuidado de la salud de la población de Lesbianas, Gays, Bisexuales, Travestis, Transexuales, Transgénero, Intersexuales $(\mathrm{LGBTI}+)$ y otras variaciones de género u orientación sexual que residen en Hogares para Ancianos (HP). Métodos: revisión de alcance, en la que se analizaron las bases de datos de PubMed, Web of Science, Scopus y Biblioteca Virtual en Salud y estudios agregados de otras fuentes. Tras la evaluación de dos revisores independientes, se seleccionaron 19 publicaciones para componer la muestra. Resultados: los estudios se agruparon en dos categorías. Consideraciones finales: los HP son espacios poco inclusivos, donde no se consideran las demandas de la población LGBTI+ anciana debido a la cis-heteronormatividad vigente en estos lugares. La formación y sensibilización de los profesionales de la salud sobre la temática LGBTI+ es una herramienta que puede hacer que dichos espacios sean más inclusivos para esta población.

Descriptores: Minorías Sexuales y de Género; Hogares para Ancianos; Prestación de Atención de Salud; Enfermería; Personal de Salud. 


\section{INTRODUCTION}

Contemporaneity highlights a situation in which internalized ideologies about old age and elders are resistant to changes ${ }^{(1)}$. Old age is usually characterized by the perspective of asexuality and androgyny, the aged body is almost always seen as devoid of sexuality and desire ${ }^{(2)}$. One of the dilemmas is in the fusion between the sex-gender system in force in society and the oppressions that permeate it, i.e., the social stereotypes that this population faces due to sexuality, sexual orientation and gender identity ${ }^{(3)}$.

Today it is observed that the proportion of people over 60 years old grows faster than that of other age groups ${ }^{(4)}$. World Population Prospects pointed out that by 2050 , one in six people in the world will be over $65^{(5)}$. With this, a series of new challenges for the country arises when the subject is aging, which makes this theme more and more recurrent in debates on public health and social security policies ${ }^{(6)}$.

It is important to highlight that, despite the absence of accurate census data for LGBTI+ (Lesbians, Gays, Bisexuals, Transvestites, Transsexuals, Intersexual) individuals and other gender identities, the demographic transition also occurs in the generation of elders who recognize themselves as such. However, this population requires more attention from the State to reduce inequities and health disparities, as they suffer double discrimination - by age and sexuality - and present poor health results, less chance of resorting to medical services, higher rates of depression, disability physical and financial barriers to healthcare ${ }^{(7-9)}$.

In this scenario of indispensability of embracement in formal support networks necessary for old age, with housing linked to health care being a protective factor for elders ${ }^{(10)}$, Nursing Homes $(\mathrm{NH})$ appear. Although they are not recent establishments, their approach has been reframed and improved considering the current demands of population aging. They are characterized as collective households of people aged 60 or over, with or without family support, under conditions of freedom, dignity and citizenship ${ }^{(11)}$.

Considering this process of institutionalizing elders, the provision of services in these spaces must address the needs of LGBTI+ elders, including respect for their sexual orientation and gender identity ${ }^{(12)}$. Studies show that approximately one fifth of LGBTI+ elders do not disclose their sexual orientation or gender identity to health professionals for fear of not receiving appropriate care ${ }^{(13)}$. The literature points to a deficit in the production of studies on LGBTI+ elders, including in health sciences ${ }^{(14)}$. Thus, knowing the scientific production on health care for LGBTI+ elders living in $\mathrm{NH}$ can contribute to the restructuring of this type of service, supporting the creation of public policies and training strategies for health professionals, expanding the sense of dignity and social inclusion of this population. In addition to its social relevance, this study can support further research and favor the development of this topic in academia.

\section{OBJECTIVE}

To describe and analyze the scientific production on health care for Lesbians, Gays, Bisexuals, Transvestites, Transsexuals, Transgenders, Intersex (LGBTI+) and other variations of gender or sexual orientation living in Nursing Homes (NHs).

\section{METHODS}

\section{Research question identification and inclusion criteria}

This is a literature scoping review ${ }^{(15)}$ that used the PCC strategy to elaborate the research question: how does the health care of LGBTI+ elders living in $\mathrm{NH}$ take place? "P" corresponded to the population (LGBTI+ elders), " $\mathrm{C}$ ", to the concept that was intended to be investigated (health care) and " $\mathrm{C}$ ", to $\mathrm{NH}$.

Studies whose population was composed of elders living in $\mathrm{NH}$ were included, and those carried out in places where health care was not offered were excluded. This review included primary studies, review studies, theses and dissertations and technical documents that fit the selection criteria. Editorial texts and book chapters were not included. There was no time limit for the search, and studies in Portuguese, English, and Spanish were included.

\section{Identification of relevant studies}

Database search was conducted between September 2019 and March 2020 by two independent reviewers, authors of this study, including publications from the Virtual Health Library, PubMed, Scopus and Web of Science databases. These bases were chosen in order to cover national and international publications dealing with the theme at different levels of health care. National descriptors were selected on the Health Sciences Descriptors (DeCS) platform, and international descriptors using the PubMed platform Medical Subject Headings (MeSH) research method. Keywords used by the authors were also used. "LGBT" and "ILPI" were the descriptors in Portuguese used, as well as their English counterparts "Sexual and Gender Minorities", "Homes for the Aged", "Nursing Homes" and "Long Term Care". In both languages, these terms have been combined with the Boolean operator AND. The search strategy adopted in each database, the descriptors and the number of publications found are described in Chart 1.

Chart 1 - Databases, search strategies and publications found, São Paulo, São Paulo, Brazil, 2020

\begin{tabular}{|c|c|c|c|}
\hline Databases & Serch strategy & $\begin{array}{c}\text { Recovered } \\
\text { studies }\end{array}$ & $\begin{array}{c}\text { Selected } \\
\text { studies }\end{array}$ \\
\hline $\begin{array}{l}\text { Virtual } \\
\text { Health } \\
\text { Library }\end{array}$ & $\begin{array}{l}\text { "Minorias Sexuais e de Gênero" } \\
\text { AND"Instituição de Longa } \\
\text { Permanência para Idosos" }\end{array}$ & 7 & 4 \\
\hline \multirow{3}{*}{ PubMed } & $\begin{array}{l}\text { "Sexual and Gender } \\
\text { Minorities" AND "Homes for } \\
\text { the Aged" }\end{array}$ & 7 & 4 \\
\hline & Igbt AND"nursing homes" & 10 & 5 \\
\hline & Igbt AND "long term care" & 18 & 8 \\
\hline \multirow{3}{*}{ Scopus } & $\begin{array}{c}\text { "Sexual and Gender } \\
\text { Minorities" AND "Homes for } \\
\text { the Aged" }\end{array}$ & 5 & 3 \\
\hline & lgbt AND "nursing homes" & 15 & 7 \\
\hline & lgbt AND“long term care" & 32 & 10 \\
\hline \multirow{3}{*}{$\begin{array}{l}\text { Web of } \\
\text { science }\end{array}$} & $\begin{array}{c}\text { "Sexual and Gender } \\
\text { Minorities" AND "Homes for } \\
\text { the Aged" }\end{array}$ & 0 & 0 \\
\hline & Igbt AND "nursing homes" & 7 & 2 \\
\hline & lgbt AND"long term care" & 24 & 9 \\
\hline
\end{tabular}




\section{Study selection for this review}

Through this search strategy, 125 publications were identified. In addition to these, three studies were obtained from other sources by searching the references of the researched studies and were included in the review. After excluding 76 duplicate articles and 10 publications that did not meet the inclusion criteria by reading title, 42 studies were selected for reading abstract, of which five were excluded for not meeting the inclusion criteria. Finally, the remaining 37 studies were read in full. Of these, 18 were discarded and 19 were included in the review, as shown in the PRISMA flow chart (Figure 1) below.

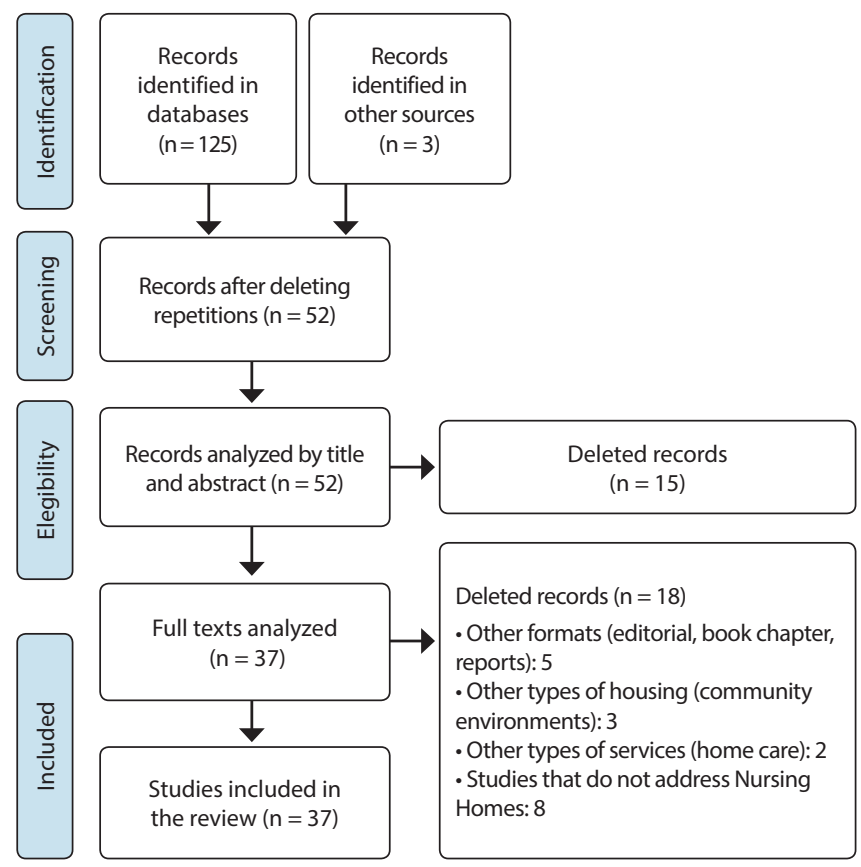

Source: Moher D, Liberati A, Tetzlaff J, Altman DG, The PRISMA Group (2009). Preferred Reporting Items for Systematic Reviews and Meta-Analyses: The PRISMA Statement. PLoS Med 6(6): e1000097. doi:10.1371/journal.pmed1000097.

Figure 1 - PRISMA flowchart for study selection and inclusion process

\section{RESULTS}

\section{Characteristics of studies}

Most studies included in this review $(n=16)$ were published in the last five years, indicating that the concern with inclusive themes for the LGBTI+ population is a recent phenomenon. Most publications originated in the United States of America (USA) ( $n=9)$, followed by the United Kingdom $(n=5)$, Canada $(n=4)$, and Spain $(n=1)$. As for the method adopted in the investigations, mostly qualitative approaches were adopted $(n=11)$ with LGBTI+ elders, $\mathrm{NH}$ workers (managers, health professionals) and members of civil society LGBTI+ and human rights activists as participants (Chart 2).

\section{Insecurity and prejudice in health care for Lesbian, Gay, Bisexual, Transvestite, Transsexual, Transgender, Inter- sexual elders in Nursing Homes}

In this category, studies were included that analyze the characteristics of $\mathrm{NH}$ and the perception of LGBTI+ elders on aspects related to inclusive care, fundamental points for the identification of weaknesses, planning and execution of actions that transform the reality in these institutions. These individuals are more concerned with long-term health care options. LGBTI+ elders can lose social capital through actions associated with housing in aging, but they can also develop and expand it, although important inequalities must be considered ${ }^{(29)}$. Operating facilities have little or no information available regarding inclusion and compromised care for elders of sexual and gender minorities ${ }^{(30)}$.

$\mathrm{NHs}$ are considered unsafe environments by residents, with the ability to raise the potential for social isolation, decrease their independence and decision-making capacity and increase their vulnerability to negative beliefs and perceptions related to their LGBTI+ identity ${ }^{(24)}$. Several stressful events have been found for LGBTI+ elders in $\mathrm{NH}$, such as fear of encountering prejudice and receiving precarious care based on sexual orientation, gender identity and expression, anticipatory stress related to the concealment of their identities and associated suicidal ideation $^{(16,20,24)}$.

Chart 2 - Characterization of publications regarding author, year, country, objective, method, participants and results, São Paulo, São Paulo, Brazil. 2020

\begin{tabular}{|c|c|c|c|c|}
\hline $\begin{array}{l}\text { Author/Year/ } \\
\text { Country }\end{array}$ & Objective & Method & Participants & Results \\
\hline $\begin{array}{l}\text { Furlotte C, } \\
\text { Gladstone JW, Cosby } \\
\text { RF, Fitzgerald KA. } \\
\text { 2016. Canada }{ }^{(16)} \text {. }\end{array}$ & $\begin{array}{l}\text { To describe and analyze the } \\
\text { expectations, desires and } \\
\text { specificities of care for lesbian } \\
\text { and gay couples regarding the } \\
\text { possibility of living in a NH and } \\
\text { needing home care. }\end{array}$ & $\begin{array}{l}\text { A qualitative study carried out } \\
\text { with lesbian and gay couples, } \\
\text { carried out through a semi- } \\
\text { structured questionnaire, } \\
\text { telephone interviews and face-to- } \\
\text { face interviews. }\end{array}$ & $\begin{array}{l}12 \text { couples: } 24 \\
\text { participants, } \\
\text { four gay couples } \\
\text { and eight } \\
\text { lesbian couples. }\end{array}$ & $\begin{array}{l}\text { The main problems faced in } \mathrm{NH} \\
\text { and home care were discrimination, } \\
\text { concealment of identity, emotional } \\
\text { and physical exhaustion and the } \\
\text { need for specificity in the care } \\
\text { offered. }\end{array}$ \\
\hline $\begin{array}{l}\text { Willis P, Almack K, } \\
\text { Hafford-Letchfield T, } \\
\text { Simpson P, Billings B, } \\
\text { Mall N. 2018. United } \\
\text { Kingdom }^{(17)} \text {. }\end{array}$ & $\begin{array}{l}\text { To assess LGBTI+ inclusion } \\
\text { in NH based on research } \\
\text { produced in partnership } \\
\text { between researchers from } \\
\text { academia and the LGBTI+ } \\
\text { community. }\end{array}$ & $\begin{array}{l}\text { A qualitative study with } \\
\text { members of the LGBTI+ } \\
\text { community who served as } \\
\text { auditors to assess the degree of } \\
\text { inclusion of older LGBTI+ people } \\
\text { in six NH. During assessment, } \\
\text { they promoted training, lasting } \\
\text { four months, for employees. }\end{array}$ & $\begin{array}{l}37 \text { participants } \\
\text { (home staff, } \\
\text { managers and } \\
\text { community } \\
\text { consultants). }\end{array}$ & $\begin{array}{l}\text { The gain between training } \\
\text { employees and managers of } \\
\text { long-term care homes has reached } \\
\text { debates about what the space } \\
\text { needs are, to make it more inclusive } \\
\text { for LGBTI+ elders. }\end{array}$ \\
\hline $\begin{array}{l}\text { Sussman T, Brotman } \\
\text { S, Maclntosh H, } \\
\text { Chamberland L, } \\
\text { MacDonnell J, } \\
\text { Daley A, et al. } 2018 . \\
\text { Canada } \\
\text { (18). }\end{array}$ & $\begin{array}{l}\text { To analyze the strategies } \\
\text { adopted and used by } \\
\mathrm{NH} \text { to become reference } \\
\text { environments in LGBTI+ } \\
\text { inclusion. }\end{array}$ & $\begin{array}{l}\text { A qualitative study carried } \\
\text { out through semi-structured } \\
\text { telephone interview with NH } \\
\text { administrators and, later, a } \\
\text { one-to-one conversation, held } \\
\text { in two days. }\end{array}$ & $\begin{array}{l}32 \mathrm{NH} \text { and } 25 \\
\text { participants. }\end{array}$ & $\begin{array}{l}\text { The most used strategies to make } \\
\mathrm{NH} \text { inclusive places were the training } \\
\text { of caregivers and the holding of } \\
\text { educational events with programming } \\
\text { on LGBTI+ themes, such as showing } \\
\text { films or round tables. }\end{array}$ \\
\hline
\end{tabular}




\begin{tabular}{|c|c|c|c|c|}
\hline $\begin{array}{l}\text { Author/Year/ } \\
\text { Country }\end{array}$ & Objective & Method & Participants & Results \\
\hline $\begin{array}{l}\text { Hafford-Letchfield } \\
\text { T, Simpson P, Willis } \\
\text { PB, Almack K. } 2018 . \\
\text { United Kingdom }{ }^{(19)} \text {. }\end{array}$ & $\begin{array}{l}\text { To describe an action research } \\
\text { initiative called Care Home } \\
\text { Challenge, in which } \mathrm{NH} \\
\text { collaborated to assess and } \\
\text { develop their services. }\end{array}$ & $\begin{array}{l}\text { A formal assessment was } \\
\text { carried out involving qualitative } \\
\text { interviews before and after } \\
\text { intervention. The combination } \\
\text { of community participation } \\
\text { with the experiences of workers } \\
\text { and managers helped in } \\
\text { the collective exploration of } \\
\text { solutions to problems related to } \\
\text { inclusion. }\end{array}$ & $\begin{array}{l}\text { Six managers } \\
\text { of NH and eight } \\
\text { volunteers from } \\
\text { the LGBTI+ } \\
\text { community as } \\
\text { community } \\
\text { counselors. }\end{array}$ & $\begin{array}{l}\text { Before the intervention, managers } \\
\text { acknowledged the low levels of } \\
\text { awareness among employees and } \\
\text { service users about the experience } \\
\text { and the needs to support LGBTI+ } \\
\text { individuals. Most reported having } \\
\text { no experience with residents } \\
\text { identified as LGBTI+. }\end{array}$ \\
\hline $\begin{array}{l}\text { Putney JM, Keary S, } \\
\text { Hebert N, Krinsky } \\
\text { L, Halmo R. } 2018 . \\
\text { United States }{ }^{(20)} \text {. }\end{array}$ & $\begin{array}{l}\text { To investigate the current } \\
\text { and anticipated needs and } \\
\text { concerns of LGBTI+ elders in } \\
\mathrm{NH} \text {. }\end{array}$ & $\begin{array}{l}\text { A qualitative study carried out } \\
\text { through seven focus groups, } \\
\text { in which participants shared } \\
\text { important characteristics and } \\
\text { a series of experiences, desires, } \\
\text { concerns and fears regarding } \\
\text { the focus of the discussion. }\end{array}$ & $\begin{array}{l}50 \text { participants } \\
\text { self-identified } \\
\text { as LGBTI+ and } \\
\text { aged between } \\
55 \text { to } 87 \text { years. }\end{array}$ & $\begin{array}{l}\text { The main themes identified were: } \\
\text { the availability or not of resources, } \\
\text { values and previous experiences, } \\
\text { which shaped expectations and } \\
\text { fears. As for these fears, they } \\
\text { expressed two main areas of need: } \\
\text { inclusive environments for LGBTI+ } \\
\text { individuals and a staff of trained } \\
\text { professionals who are sensitive to } \\
\text { the issues of this population. }\end{array}$ \\
\hline $\begin{array}{l}\text { Hardacker CT, } \\
\text { Rubinstein B, } \\
\text { Hotton A, Houlberg } \\
\text { M. 2014. United } \\
\text { States }^{(21)} \text {. }\end{array}$ & $\begin{array}{l}\text { To enable Health Education } \\
\text { for institutionalized LGBTI+ } \\
\text { elders and in health settings, } \\
\text { for nurses and health } \\
\text { professionals. }\end{array}$ & $\begin{array}{l}\text { A qualitative and quantitative } \\
\text { study, during which training } \\
\text { sessions were held in } 23 \text { health } \\
\text { facilities (academia, hospitals } \\
\text { and NH), through the HEALE } \\
\text { curriculum (Health Education } \\
\text { About LGBTI+ Elders) and } \\
\text { application of a pre- and post- } \\
\text { training. }\end{array}$ & $\begin{array}{l}848 \text { health } \\
\text { professionals. }\end{array}$ & $\begin{array}{l}\text { The study demonstrated the } \\
\text { course's effectiveness in informing, } \\
\text { raising awareness, training and } \\
\text { promoting changes in health care } \\
\text { for LGBTI+ elders. }\end{array}$ \\
\hline $\begin{array}{l}\text { Committee AGSE. } \\
\text { 2015. United } \\
\text { States } \\
\text { (22). }\end{array}$ & $\begin{array}{l}\text { To describe guidelines to } \\
\text { promote the inclusion of } \\
\text { LGBTI+ elders in healthcare } \\
\text { environments and } \mathrm{NH} \text {. }\end{array}$ & $\begin{array}{l}\text { A theoretical study that } \\
\text { proposes guidelines on the } \\
\text { topic. }\end{array}$ & - & $\begin{array}{l}\text { Topics and steps needed to reduce } \\
\text { health disparities, highlight the } \\
\text { need for training for caregivers, the } \\
\text { importance of academic research } \\
\text { and the promotion of dignified } \\
\text { and adequate inclusion of LGBTI+ } \\
\text { residents in NH. }\end{array}$ \\
\hline $\begin{array}{l}\text { Caceres BA, Travers } \\
\text { J, Primiano JE, } \\
\text { Luscombe RE, } \\
\text { Dorsen C. } 2019 . \\
\text { United States }{ }^{(23)} \text {. }\end{array}$ & $\begin{array}{l}\text { To analyze professionals' } \\
\text { perspectives working in } \\
\mathrm{NH} \text { and LGBTI+ individuals } \\
\text { on issues and needs of this } \\
\text { population. }\end{array}$ & $\begin{array}{l}\text { A systematic review, which } \\
\text { presented an analysis of } 19 \\
\text { studies. }\end{array}$ & - & $\begin{array}{l}\text { The main themes that emerged } \\
\text { were: lack of knowledge and } \\
\text { training on LGBTI+ health issues } \\
\text { and attitudes of professionals } \\
\text { towards LGBTI+ elders; concern } \\
\text { with NH planning, fear of } \\
\text { discrimination by professionals and } \\
\text { inclusive NH solutions. }\end{array}$ \\
\hline $\begin{array}{l}\text { Kortes-Miller K, } \\
\text { Boulé J, Wilson K, } \\
\text { Stinchcombe A. } \\
\text { 2018. Canada }{ }^{(24)} \text {. }\end{array}$ & $\begin{array}{l}\text { To explore the fears and hopes } \\
\text { of older LGBTI+ people when } \\
\text { considering entering Long- } \\
\text { Term Care Facilities. }\end{array}$ & $\begin{array}{l}\text { A qualitative study, carried out } \\
\text { through focus groups. }\end{array}$ & $\begin{array}{l}23 \text { participants } \\
\text { identified as part } \\
\text { of the LGBTI+ } \\
\text { community. }\end{array}$ & $\begin{array}{l}\text { The results were organized into } \\
\text { four main themes: strong fears, } \\
\text { social isolation, concerns about } \\
\text { dependency and safe and inclusive } \\
\text { spaces. }\end{array}$ \\
\hline $\begin{array}{l}\text { Smith RW, Altman } \\
\text { JK, Meeks S, Hinrichs } \\
\text { KL. 2018. United } \\
\text { States }^{(25)} \text {. }\end{array}$ & $\begin{array}{l}\text { To question health } \\
\text { professionals who provided } \\
\text { mental health care at NH about } \\
\text { their skills, training and barriers } \\
\text { to working with LGBTI+ elders. }\end{array}$ & $\begin{array}{l}\text { A qualitative study carried out } \\
\text { through a virtual platform on } \\
\text { mental health care. }\end{array}$ & $\begin{array}{l}57 \text { professionals, } \\
\text { among them } \\
\text { psychologists, } \\
\text { social workers, } \\
\text { psychiatrists and } \\
\text { nurses, with an } \\
\text { average age of } \\
52 \text { years. }\end{array}$ & $\begin{array}{l}\text { Professionals reported that LGBTI+ } \\
\text { issues were relevant to their } \\
\text { practice }(87 \%) \text {, that they felt a little } \\
\text { or well prepared to work with this } \\
\text { population }(76 \%) \text { and were also a } \\
\text { little or very willing to learn more } \\
(90 \%) \text {. }\end{array}$ \\
\hline $\begin{array}{l}\text { Donaldson WV, } \\
\text { Vacha-Haase T. } 2016 . \\
\text { United States } \\
\end{array}$ & $\begin{array}{l}\text { To assess the LGBTI+ } \\
\text { cultural competence of NH } \\
\text { employees, identify the } \\
\text { needs regarding the training } \\
\text { of these professionals and } \\
\text { develop a structure so that the } \\
\text { LGBTI+ cultural competence is } \\
\text { understood. }\end{array}$ & $\begin{array}{l}\text { A qualitative study during } \\
\text { which four focus groups were } \\
\text { formed, with employees from } \\
\text { different areas of three } \mathrm{NH} \text {, for } \\
\text { discussions. }\end{array}$ & 22 employees. & $\begin{array}{l}\text { The qualitative analysis of the } \\
\text { focus group discussions revealed } \\
\text { a central category identified as } \\
\text { "Sensitivity of the NH staff to } \\
\text { residents' sexual orientations } \\
\text { and gender identities", and eight } \\
\text { main categories that described } \\
\text { and explained the components of } \\
\text { LGBTI+ cultural competence among } \\
\text { study participants. }\end{array}$ \\
\hline
\end{tabular}




\begin{tabular}{|c|c|c|c|c|}
\hline $\begin{array}{l}\text { Author/Year/ } \\
\text { Country }\end{array}$ & Objective & Method & Participants & Results \\
\hline $\begin{array}{l}\text { Willis P. 2017. United } \\
\text { Kingdom }^{(27)} \text {. }\end{array}$ & $\begin{array}{l}\text { To discuss the criticality of the } \\
\text { visibility of LGBTI+ elders and } \\
\text { the inclusion of this population } \\
\text { in the main healthcare } \\
\text { environments. }\end{array}$ & A theoretical study. & - & $\begin{array}{l}\text { The need to add large-scale } \\
\text { education sessions to the visibility } \\
\text { strategies in order to promote } \\
\text { the staff improvement and the } \\
\text { consequent preparation to } \\
\text { challenge homophobic comments } \\
\text { and support the people affected } \\
\text { by them. }\end{array}$ \\
\hline $\begin{array}{l}\text { Jihanian LJ. } 2013 . \\
\text { United States } \\
\text { (28). }\end{array}$ & $\begin{array}{l}\text { To investigate NH professionals' } \\
\text { knowledge, attitudes and skills } \\
\text { to respond to the needs of } \\
\text { LGBTI+ elders. }\end{array}$ & $\begin{array}{l}\text { A qualitative study of focus } \\
\text { groups and interviews with } \\
\text { LGBTI+ elders. }\end{array}$ & $\begin{array}{l}\text { Seven LGBTI+ } \\
\text { elders. }\end{array}$ & $\begin{array}{l}15 \text { domains were identified } \\
\text { corresponding to the needs of } \\
\text { LGBTI+ elders, eight related to } \\
\text { the types of knowledge needed, } \\
\text { four to the idea of what attitudes } \\
\text { NH providers need to have and } \\
\text { three to the types of skills that are } \\
\text { indispensable to assist these elders. }\end{array}$ \\
\hline $\begin{array}{l}\text { King A, Cronin } \\
\text { A. } 2016 . \text { United } \\
\text { States }^{(29)} \text {. }\end{array}$ & $\begin{array}{l}\text { To carry out a critical reflection, } \\
\text { intervention and discussion } \\
\text { about housing issues for } \\
\text { LGBTI+ people during aging, } \\
\text { according to the context of } \\
\text { social capital theory. }\end{array}$ & $\begin{array}{l}\text { A theoretical study based on } \\
\text { an analysis of Robert Putnam } \\
\text { and Pierre Bourdieu works. } \\
\text { The author based himself on } \\
\text { existing studies on housing for } \\
\text { LGBTI+ aging, identifying the } \\
\text { main concerns and framing } \\
\text { those concerns around the } \\
\text { social capital theory. }\end{array}$ & - & $\begin{array}{l}\text { Service providers can be } \\
\text { ignorant and discriminatory in } \\
\text { the way they deal with LGBTI+ } \\
\text { elders, especially with trans } \\
\text { people. Heteronormativity } \\
\text { and cisnormativity can distort } \\
\text { the development of a bridge } \\
\text { between social capital, bonds and, } \\
\text { subsequently, affect well-being. }\end{array}$ \\
\hline $\begin{array}{l}\text { Benoit ID, } \\
\text { Kordrostami E, } \\
\text { Foreman J. } 2020 . \\
\text { United States }{ }^{(30)} \text {. }\end{array}$ & $\begin{array}{l}\text { To analyze the perception of } \\
\text { LGBTI+ elders regarding their } \\
\text { experiences in health services. }\end{array}$ & $\begin{array}{l}\text { A phenomenological study } \\
\text { that focused on the emotional } \\
\text { domain and based on } \\
\text { participants' experiences. } \\
\text { Interviews were conducted } \\
\text { in focus groups at an LGBTI+ } \\
\text { organization. }\end{array}$ & Eight gay men. & $\begin{array}{l}\text { Three main themes were exposed } \\
\text { based on the interviews: the quality } \\
\text { of daily health care, the concern } \\
\text { for financial stability and the future } \\
\text { and access to culturally competent } \\
\text { Long-Term Care Facilities. }\end{array}$ \\
\hline $\begin{array}{l}\text { Green M. } 2016 . \\
\text { Canada }^{(31)} \text {. }\end{array}$ & $\begin{array}{l}\text { To analyze the experience of } \\
\text { LGBTI+ elders living in } \mathrm{NH} \text {. }\end{array}$ & $\begin{array}{l}\text { A qualitative study developed } \\
\text { through semi-structured } \\
\text { interviews. }\end{array}$ & $\begin{array}{l}\text { Six individuals: } \\
\text { two LGBTI+ } \\
\text { people living in } \\
\text { NH, two LGBTI+ } \\
\text { activists and two } \\
\text { NH workers. }\end{array}$ & $\begin{array}{l}\text { The interviews pointed to three } \\
\text { main themes: insecurity taking } \\
\text { over sexuality due to fear of } \\
\text { discrimination due to sexual } \\
\text { orientation, the impact of } \\
\text { relationships, inside and outside } \\
\text { home, with professionals, residents } \\
\text { and family and the impacts of } \\
\text { changing the environment, i.e., the } \\
\text { transition between leaving home to } \\
\text { be placed in a NH. }\end{array}$ \\
\hline $\begin{array}{l}\text { Mansilla CF, } \\
\text { Rodríguez-Martín B. } \\
\text { 2019. Espanha }{ }^{(32)} \text {. }\end{array}$ & $\begin{array}{l}\text { To analyze the existing } \\
\text { evidence in the literature about } \\
\text { the knowledge of professionals } \\
\text { in Long-Term Care Facilities } \\
\text { about the sexuality of } \\
\text { institutionalized elders. }\end{array}$ & $\begin{array}{l}\text { A systematic review. A search for } \\
\text { qualitative studies, published } \\
\text { in English or Spanish, was } \\
\text { carried out in eight databases, } \\
\text { in the gray literature (doctoral } \\
\text { theses) and in the references } \\
\text { of the included articles. 1,698 } \\
\text { potentially relevant articles were } \\
\text { collected and six articles were } \\
\text { selected for this review. }\end{array}$ & $\begin{array}{l}111 \\
\text { professionals } \\
\text { from Long-Term } \\
\text { Care Facilities. }\end{array}$ & $\begin{array}{l}\text { Seven categories emerged after the } \\
\text { analysis of the included studies, of } \\
\text { which the following stand out: the } \\
\text { influence of negative stereotypes } \\
\text { on the perceptions of professionals } \\
\text { about sexuality in elders, the } \\
\text { reactions and interpretations } \\
\text { (positive and negative) of the } \\
\text { professionals of Long-Term Care } \\
\text { Facilities to the sexual expression } \\
\text { of institutionalized elders and the } \\
\text { residents' need for privacy for the } \\
\text { expression of sexuality. }\end{array}$ \\
\hline $\begin{array}{l}\text { Willis P, Maegusuku- } \\
\text { Hewett T, Raithby M, } \\
\text { Miles P. 2014. United } \\
\text { Kingdom }^{(33)} \text {. }\end{array}$ & $\begin{array}{l}\text { To compare the expectations of } \\
\text { LGBTI+ elders not living in } \mathrm{NH} \\
\text { with the findings of managers } \\
\text { and health professionals } \\
\text { working in these institutions. }\end{array}$ & $\begin{array}{l}\text { A qualitative and quantitative } \\
\text { study carried out through a } \\
\text { semi-structured questionnaire } \\
\text { applied to focus groups of } \mathrm{NH} \\
\text { workers, and semi-structured } \\
\text { interviews conducted with } \\
\text { LGBTI+ elders from the } \\
\text { community in general. }\end{array}$ & $\begin{array}{l}70 \text { participants, } \\
\text { among them } 14 \\
\text { were part of the } \\
\text { NH professional } \\
\text { staff, } 27 \text { were } \\
\text { managers of } \\
\text { these Long-Term } \\
\text { Care Facilities, } \\
\text { and } 29 \text { were } \\
\text { LGBTI+ elders } \\
\text { aged } 50 \text { - } 76 \text { years. }\end{array}$ & $\begin{array}{l}\text { Interviews with LGBTI+ elders } \\
\text { highlighted the desire not to reside } \\
\text { in a NH for fear of discrimination. } \\
\text { Moreover, they presented the idea } \\
\text { of the need for specific institutions } \\
\text { for the LGBTI+ community, in order } \\
\text { to avoid the oppressions existing in } \\
\text { heteronormative environments. }\end{array}$ \\
\hline
\end{tabular}




\begin{tabular}{|l|l|l|l|l|}
\hline $\begin{array}{l}\text { Author/YearI } \\
\text { Country }\end{array}$ & Objective & Method & Participants & Results \\
\hline $\begin{array}{l}\text { Willis P, Raithby M, } \\
\text { Maegusuku-Hewett }\end{array}$ & $\begin{array}{l}\text { To understand how } \\
\text { professionals who provide } \\
\text { support to elders of different } \\
\text { sexual identities can help to } \\
\text { United Kingdom }\end{array}$ & $\begin{array}{l}\text { A mixed study. Use of focus } \\
\text { improups, semi-structured } \\
\text { interviews and self-administered } \\
\text { questionnaires. }\end{array}$ & $\begin{array}{l}\text { 62 participants } \\
\text { formed the } \\
\text { focus groups } \\
\text { and 121 } \\
\text { questionnaires } \\
\text { were carried out. }\end{array}$ & $\begin{array}{l}\text { Most of interviewees indicated } \\
\text { tolerant attitudes towards elders' } \\
\text { sexual lives, but the results } \\
\text { indicated gaps in the knowledge of } \\
\text { changes in their sexual functioning } \\
\text { and important aspects of the } \\
\text { LGBTI+ history. }\end{array}$ \\
\hline
\end{tabular}

A study pointed out that, although some residents have never suffered prejudice, the possibility of such an attitude happening is enough to reproduce insecurities and fears. Being a LGBTI+ in a Long-Term Care Facility requires support from the community, residents and management of the facility itself ${ }^{(31)}$.

Some works cited narratives of LGBT-phobia committed by health professionals and other residents of $\mathrm{NH}$. These infractions included the denial of the social name, delegitimization of the stable union, separation of the couple at the moment when both start to live in the same $\mathrm{NH}$, where the health professionals put each partner in a different room, prohibiting demonstration of affection, prohibiting bathing with other residents of the same gender and disregarding their partners' opinions in decisionmaking regarding treatment. Among the most serious infractions, it is worth noting the lack of understanding of gender identity when the loss of autonomy due to neurological changes coexists associated with the increase in the degree of dependence in activities of daily living ${ }^{(24,30)}$. It is at that moment that individuals who identify with the gender opposite to the gender designated at birth start to be dressed and treated by cis-heteronormativity.

Being visible in shared residential environments is not, in itself, a sufficient strategy to change individual views and attitudes and promote more inclusive care environments ${ }^{(27)}$. Elders revealed that they preferred to live and be cared for in facilities that included people of all races, ethnicities, genders and sexualities ${ }^{(20)}$. There is an urgent need for research that examines the experience of LGBTI+ elders who have received or are currently receiving care in $\mathrm{NHs}^{(23)}$.

\section{Professional training for dignified and inclusive assistance for Lesbian, Gay, Bisexual, Transvestite, Transsexual, Trans- gender, Intersexual elders}

In this category, studies were included that investigated strategies aimed at training professionals working in $\mathrm{NH}$, in order to promote awareness and approach of the LGBTI+ population in an inclusive and non-judgmental manner. Although the institutions affirm themselves to be inclusive, little is known about the strategies used for this purpose ${ }^{(18)}$, which supports the importance of presenting these findings.

A systematic review pointed to the need to promote changes in $\mathrm{NH}$ professionals' attitudes towards sexuality ${ }^{(32)}$. A strategy adopted to overcome this problem may be to personalize care to ensure respect for diversity and allow individuals to feel able to discuss their support needs with the staff, regardless of sexual orientation and gender identity ${ }^{(19)}$.

Furthermore, lack of training is consistent with the unfamiliarity of professionals with health problems and treatments related to the LGBTI+ population ${ }^{(25)}$. A study that conducted focus groups with
$\mathrm{NH}$ professionals highlighted that the staff was looking for ways to learn how to be sensitive to LGBTI+ residents. However, they showed tension between wanting to provide an equal standard of assistance to all residents and fearing that they would show favoritism or special treatment, being considered non-professionals ${ }^{(26)}$. Lack of sex education and professional awareness reflects the need to train professionals to understand residents' sexual needs and effectively resolve conflicts or difficult situations ${ }^{(32)}$.

When analyzing the strategies for health education of professionals, one of the articles brings the study on the Health Education About LGBT Elders (HEALE), created and formalized by the Howard Brown Health Center, USA. The HEALE educational curriculum lists professional development for healthcare providers and care staff members who are interested in increasing their ability to care for LGBTI+ patients. The reports presented in the study, based on the training of 848 participating nurses, $\mathrm{NH}$ workers, demonstrated the course's effectiveness in informing, raising awareness, training and promoting changes related to health care provided to LGBTI+ elders, as they establish a standard of practice in nursing management to increase nurses' confidence to provide specific care to this population ${ }^{(21)}$.

Studies have pointed to the denial of the presence of LGBTI+ people and the imposing heteronormativity in $\mathrm{NH}$. A study with $\mathrm{NH}$ professionals showed that the staff assumes that elders clients are heterosexual and non-transgender, and react in a discriminatory manner ${ }^{(28)}$. Professionals involved in long-term care for elders need to be aware of the historical legacy of discrimination against LGBTI+ people and how it can impact access to health services and social assistance or in residential environments ${ }^{(34)}$. Interviews with $\mathrm{NH}$ staff and managers pointed to the gap in the knowledge of specificities of care with LGBTI+ elders, since they reinforced the "equal treatment for all" discourse and the belief that elders should expose their sexualities so that the heterosexual presumption disappear ${ }^{(33)}$.

It was also observed that a main objective of education and training was to emphasize the fundamental importance that all LGBTI+ employees and service users receive the same dignified and respectful treatment offered to heterosexuals. Moreover, an example of how to achieve this result is the adoption of a logo or even the display of LGBTI+ posters and flags on site, indicating that the staff is well aware of lesbian, gay, bisexual and transgender clients' concerns $^{(18)}$.

Co-production between academia and the community promoted discussion on public policies, ways of care and increased visibility, as it takes into account the experiences lived by LGBTI+ community members ${ }^{(17,23)}$. The need to disseminate knowledge about the specificities and particularities of care related to assistance to LGBTI+ individuals in health and institutional settings was also pointed out ${ }^{(21)}$. 


\section{DISCUSSION}

The health field tends to follow a single direction, that of compulsory cis-heteronormativity. The assumptions, judgments and prejudices expressed by health professionals and institutions assume that all patients seen in the health system are configured as heterosexual and cisgender subjects ${ }^{(35-36)}$, or that they are devoid of sexuality ${ }^{(37-38)}$. However, health professionals and service providers are beginning to encounter a generation of politically engaged LGBTI+ elders who live openly and whose lifestyles and needs have so far not been properly included in social policies.

The articles included in this review, as well as studies from Australia $^{(38)}$, Belgium ${ }^{(39)}$, Spain ${ }^{(40)}$ and the United Kingdom ${ }^{(41)}$, pointed to the prejudice related to sexual orientation and gender identity in $\mathrm{NH}$, which generates a feeling of fear and concern in LGBTI+ elders. A routine practice that transpires in healthcare environments, including in $\mathrm{NH}$, is the obligation that elders find in "going back to the closet", hiding their gender identity and sexual orientation ${ }^{(24,38,41-42)}$. This has a negative impact on the quality of care provided, since the denial of identity leads to visible mental health problems in the assisted population. Depression, suicidal ideation, anxiety and social isolation are examples of mental disorders developed as a consequence of hiding sexual orientation and gender identity in institutionalized elders ${ }^{(13,43)}$.

The ambivalence in the judgment of $\mathrm{NH}$ resident elders'values about the fine line of taking on or not their gender identity and sexual orientation clearly reflects in the obstacles that this population faces during aging and in their old age. Even though in these places there is the possibility of aging together with other LGBTI+ people, sharing experiences and forming a support network ${ }^{(44)}$, it is necessary to modify the institutionalized approach models in health, as well as training and discussions about specificities of care crucial to care, thus preventing an increase in the rate of LGBT-phobia committed in NH.

In this setting, studies point out the dilemma between creating specific NH for LGBTI+ people in order to prevent LGBT-phobia, but with the risk of leading to segregation and accentuating the stigmatization of these elders. The ideal would be to invest in places where everyone is free to express their values, regardless of sexual orientation and gender identity ${ }^{(44)}$, which is still a challenging task in many countries. Another controversial point is the hiring of LGBTI+ people to work in these places, as long as they are empathetic in assisting this population ${ }^{(16,44)}$. Whatever the characteristics of $\mathrm{NH}$ are, it is essential to have institutional policies and concrete actions to train and develop professionals ${ }^{(45)}$ able to assist LGBTI+ elders with quality and respect.
Active Aging, marked by the preservation of autonomy and independence, shared by the World Health Organization in $2005^{(46)}$, does not cover citizens in its entirety, as being a LGBTI+ elder means facing several barriers in politics, economy, social security, and health care. In addition to the discrimination due to fragility arising from aging itself, this population also faces greater difficulties in health care, since these care delivery environments are marked by the cis-heteronormative overview ${ }^{(47)}$.

\section{Study limitations}

This study had as limitations analyzing studies in Portuguese, English, and Spanish, which made it impossible to analyze studies in other languages, especially from countries with extensive experience with institutionalized elders, such as studies in German.

\section{Contributions to nursing, health, and public policies}

The findings of this review allow to give visibility to a theme that needs better exploration by public policies for healthy aging and $\mathrm{NH}$ managers. The results pointed to a serious problem of human rights, which calls for the LGBTI+ community's activism so that the theme is based on the deliberative spheres. It also brings relevant content of health education, with the inclusion of the topic in a professional training for the health staff.

\section{FINAL CONSIDERATIONS}

The studies in this review showed that $\mathrm{NH}$ are configured as hostile spaces, where elders can regress in their self-affirmation of gender and sexual orientation so that their care is adequate. The use of the title "treating everyone as equal" does not do justice to the equity of care, as it is systematized in the heterosexist perspective. We highlight the lack of professional training in assisting LGBTI+ old age and lack of knowledge of $\mathrm{NH}$ administrators and managers, considering LGBTI+ elders' health needs and demands.

Although the Brazilian gerontological studies of the last decade follow the international trend to include aspects of the development of sexual life in the itinerary of aging and old age processes, the heterosexual perspective is still mostly considered. Moreover, the difficulty of capturing how the topic has been approached in Brazil demonstrates the scarcity of national studies on institutionalized LGBTI+ elders.

Inserting gender aspects in debate and training of health and social care workers working in $\mathrm{NH}$ transcends biological issues of aging, reaching basic human rights of respect for identity, dignified treatment and the provision of a healthy environment and respect for residents.

\section{REFERENCES}

1. Araújo L, Sá ECN, Amaral EB. Corpo e velhice: um estudo das representações sociais entre homens idosos. Psicol Cienc Prof. 2011;31(3):46881. doi: 10.1590/S1414-98932011000300004

2. Tarquino ML, Santos LV, Coutinho MIB, Cruz LHL, Brasil ML. Invisibilidade na assistência: um enfoque na atenção à saúde da população LGBT idosa. An CIEH [Internet]. 2015 [cited 2020 mar 29];2(1):1-4. Available from: http://www.editorarealize.com.br/revistas/cieh/trabalhos/ TRABALHO_EV040_MD4_SA9_ID290_26072015175127.pdf 
3. Rubin G. Políticas do sexo. São Paulo: Ubu; 2017. 144 p.

4. Vasconcelos AMN, Gomes MMF. Demographic transition: the Brazilian experience. Epidemiol Serv Saúde. 2012;21:539-48. doi: 10.5123/ S1679-49742012000400003

5. United Nations. Department of Economic and Social Affairs Population Division. World Population Prospects 2019: Highlights [Internet]. 2019 [cited 2020 Jan 15]. 46 p. Available from: https://population.un.org/wpp/Publications/Files/WPP2019_Highlights.pdf

6. Villar F, Fabà J, Serrat R, Celdrán M. Personas mayores LGBT que viven en instituciones de cuidado: desafíos y barreras para el mantenimiento de derechos sexuales. Psi Unisc. 2018;2(2):7-18. doi: 10.17058/psiunisc.v2i2.12088

7. Crenitte MRF, Miguel DF, Jacob Filho W. An approach to the peculiarities of lesbian, gay, bisexual, and transgender aging. Geriat Geront Aging. 2019;13(1):50-6. doi: 10.5327/Z2447-211520191800057

8. Caceres BA. Care of LGBTQ older adults: what geriatric nurses must know. Geriatr Nurs. 2019;40(3):342-343. doi: 10.1016/j. gerinurse.2019.05.006

9. Fredriksen-Goldsen Kl, Kim HJ, Barkan SE, Muraco A, Hoy-Ellis CP. Health disparities among lesbian, gay, and bisexual older adults: results from a population-based study. Am J Public Health. 2013;103(10):1802-9. doi: 10.2105/AJPH.2012.301110

10. Fernandes NM. A qualidade de vida em idosos institucionalizados[Dissertação]. Instituto Politécnico de Beja; Beja. 2013.

11. Ministério da Saúde (BR). Agência Nacional de Vigilância Sanitária. Resolução da Diretoria Colegiada n. 283 de 26 de setembro de 2005 [Internet]. DOU no 186, de 27 de setembro de 2005[cited 2020 Jan 15]. Available from: http://portal.anvisa.gov.br/ documents/10181/2718376/RDC_283_2005_COMP.pdf

12. Sharek DB, McCann E, Sheerin F, Glacken M, Higgins A. Older LGBT people's experiences and concerns with healthcare professionals and services in Ireland. Int J Older People Nurs. 2015;10(3):230-40. doi: 10.1111/opn.12078

13. Fredriksen-Goldsen KI, Kim HJ, Emlet CA, Muraco A, Erosheva EA, Hoy-Ellis CP. The aging and health report: disparities and resilience among lesbian, gay, bisexual, and transgender older adults. 2011. doi: 10.1037/e561402013-001

14. Cloyes KG. The silence of our science: nursing research on LGBT older adult health. Res Gerontol Nurs. 2016;9(2):92-104. doi: 10.3928/19404921-20151218-02

15. Arksey H, O'Malley L. Scoping studies: towards a methodological framework. Int J Soc Res Methodol. 2005;8(1):19-32. doi: $10.1080 / 1364557032000119616$

16. Furlotte C, Gladstone JW, Cosby RF, Fitzgerald KA. "Could We Hold Hands?" older lesbian and gay couples' perceptions of long-term care homes and home care. Can J Aging. 2016;35(4):432-46. doi: 10.1017/S0714980816000489

17. Willis P, Almack K, Hafford-Letchfield T, Simpson P, Billings B, Mall N. Turning the co-production corner: methodological reflections from an action research project to promote LGBT inclusion in care homes for older people. Int J Environ Res Public Health. 2018;15(4). doi: 10.3390/ ijerph15040695

18. Sussman T, Brotman S, Maclntosh H, Chamberland L, MacDonnell J, Daley A, et al. Supporting lesbian, gay, bisexual, \& transgender inclusivity in long-term care homes: a Canadian perspective. Can J Aging. 2018;37(2):121-32. doi: 10.1017/S0714980818000077

19. Hafford-Letchfield T, Simpson P, Willis PB, Almack K. Developing inclusive residential care for older lesbian, gay, bisexual and trans (LGBT) people: an evaluation of the Care Home Challenge action research project. Health Soc Care Community. 2018;26(2):312-20. doi: 10.1111/ hsc. 12521

20. Putney JM, Keary S, Hebert N, Krinsky L, Halmo R. "Fear Runs Deep:"The anticipated needs of LGBT older adults in long-term care. J Gerontol Soc Work. 2018;61(8):887-907. doi: 10.1080/01634372.2018.1508109

21. Hardacker CT, Rubinstein B, Hotton A, Houlberg M. Adding silver to the rainbow: the development of the nurses' health education about LGBT elders (HEALE) cultural competency curriculum. J Nurs Manag. 2014;22(2):257-66. doi: 10.1111/jonm.12125

22. Committee AGSE. American Geriatrics Society care of lesbian, gay, bisexual, and transgender older adults position statement: American Geriatrics Society Ethics Committee. J Am Geriatr Soc. 2015;63(3):423-6. doi: 10.1111/jgs.13297

23. Caceres BA, Travers J, Primiano JE, Luscombe RE, Dorsen C. Provider and LGBT individuals' perspectives on LGBT issues in long-term care: a systematic review. Gerontol. 2019;60(3):e169-e83. doi: 10.1093/geront/gnz012

24. Kortes-Miller K, Boulé J, Wilson K, Stinchcombe A. Dying in long-term care: perspectives from sexual and gender minority older adults about their fears and hopes for end of life. J Soc Work End Life Palliat Care. 2018;14(2-3):209-24. doi: 10.1080/15524256.2018.1487364

25. Smith RW, Altman JK, Meeks S, Hinrichs KL. Mental health care for LGBT older adults in long-term care settings: competency, training, and barriers for mental health providers. Clin Gerontol. 2018;42(2):198-203. doi: 10.1080/07317115.2018.1485197

26. Donaldson WV, Vacha-Haase T. Exploring staff clinical knowledge and practice with LGBT residents in long-term care: a grounded theory of cultural competency and training needs. Clin Gerontol. 2016;39(5):389-409. doi: 10.1080/07317115.2016.1182956

27. Willis P. Queer, visible, present: the visibility of older LGB adults in long-term care environments. Hous. Care Support. 2017;20(3):110-20. doi: 10.1108/HCS-04-2017-0007

28. Jihanian LJ. specifying long-term care provider responsiveness to LGBT older adults. J. Gay Lesbian Soc Serv. 2013;25(2):210-31. doi: $10.1080 / 10538720.2013 .782834$ 
29. King A, Cronin A. Bonds, bridges and ties: applying social capital theory to LGBT people's housing concerns later in life. Qual Ageing. 2016;17(1):16-25. doi: 10.1108/QAOA-05-2015-0023

30. Benoit ID, Kordrostami E, Foreman J. Senior sexual and gender minorities' perception of healthcare services: A phenomenological approach. Int J Healthc Manag. 2020. doi: 10.1080/20479700.2020.1724437

31. Green M. The experience of living in long-term care for LGBT individuals: perspectives from residents and stakeholders [Internet]. Mount Saint Vincent University. 2016 [cited 2020 Mar 18]. Available from: http://140.230.24.101:8080/xmlui/bitstream/handle/10587/1750/ MaureenGreenMAFSGNThesis2016.pdf

32. Mansilla CF, Rodríguez-Martín B. Professionals' view of sexuality in institutionalized older people: a qualitative thematic synthesis. Gerokomos [Internet]. 2019 [cited 2020 mar 30];30(4):176-180. Available from: http://scielo.isciii.es/pdf/geroko/v30n4/1134-928Xgeroko-30-04-176.pdf

33. Willis $\mathrm{P}$, Maegusuku-Hewett T, Raithby M, Miles P. Swimming upstream: the provision of inclusive care to older lesbian, gay and bisexual (LGB) adults in residential and nursing environments in Wales. Ageing Soc. 2014;36(2):282-306. doi: 10.1017/S0144686X14001147

34. Willis P, Raithby M, Maegusuku-Hewett T, Miles P. 'Everyday Advocates' for inclusive care? perspectives on enhancing the provision of longterm care services for older lesbian, gay and bisexual adults in Wales. Br J Soc Work. 2016;47(2):409-426. doi: 10.1093/bjsw/bcv143

35. Nogueira FJdS, Aragão TAP. Brazilian policy of Igbt integral health: what actually happens from the point of view of agents and health professionals. Saude Pesqui. 2019;12(3):463-70. doi: 10.17765/2176-9206.2019v12n3p463-470

36. Simpson P, Horne M, Brown LJ, Wilson CB, Dickinson T, Torkington K. Old(er) care home residents and sexual/intimate citizenship. Ageing Soc. 2017;37(2):243-265. doi: 10.1017/s0144686x15001105

37. Bauer M, Haesler E, Fetherstonhaugh D. Let's talk about sex: older people's views on the recognition of sexuality and sexual health in the health-care setting. Health Expect. 2016;19(6):1237-50. doi: 10.1111/hex.12418

38. Robinson P. Ageing fears and concerns of gay men aged 60 and over: quality in ageing \& older adults. 2016;17(1):6-15. doi: 10.1108/ QAOA-04-2015-0015

39. Mahieu L, Gastmans C. Older residents' perspectives on aged sexuality in institutionalized elderly care: a systematic literature review. Int J Nurs Stud. 2015;52(12):1891-905. doi: 10.1016/j.ijnurstu.2015.07.007

40. Villar F, Serrat R, Fabà J, Celdrán M. Staff reactions toward lesbian, gay, or bisexual (LGB) people living in residential aged care facilities (RACFs) who actively disclose their sexual orientation. J Homosex. 2015;62(8):1126-43. doi: 10.1080/00918369.2015.1021637

41. Westwood S. 'We see it as being heterosexualised, being put into a care home': gender, sexuality and housing/care preferences among older LGB individuals in the UK. Health Soc Care Commun. 2016;24(6):E155-E163. doi: 10.1111/hsc.12265

42. Stein GL, Beckerman NL, Sherman PA. Lesbian and gay elders and long-term care: identifying the unique psychosocial perspectives and challenges. J Gerontol Soc Work. 2010;53(5):421-35. doi: 10.1080/01634372.2010.496478

43. Cottrell DB. Considering the Needs of Older Sexual and Gender Minority People. J Nurse Pract. 2019;16(2):146-50. doi: 10.1016/j. nurpra.2019.11.013

44. Kottorp A, Johansson K, Aase P, Rosenberg L. Housing for ageing LGBTQ people in Sweden: a descriptive study of needs, preferences, and concerns. Scand J Occup Ther. 2016;23(5):337-46. doi: 10.3109/11038128.2015.1115547

45. Grigorovich A. The meaning of quality of care in home care settings: older lesbian and bisexual women's perspectives. Scand J Caring Sci. 2016;30(1):108-116. doi: 10.1111/scs.12228

46. Organização Mundial Da Saúde (OMS). Organização Pan-Americana de Saúde (OPAS). Envelhecimento ativo: uma política de saúde[Internet]. 2005 [cited 2020 Mar 24]. Available from: https://www.nescon.medicina.ufmg.br/biblioteca/imagem/4478.pdf

47. Henning CE. Gerontologia LGBT: velhice, gênero, sexualidade e a constituição dos "idosos LGBT". Horiz Antropol. 2017;23(47):283-323. doi: $10.1590 / \mathrm{s} 0104-71832017000100010$ 